\title{
CEO Traits, Corporate Performance, and Financial Leverage
}

\author{
Hsien-Chang Kuo ${ }^{1}$, Lie-Huey Wang ${ }^{2} \&$ Dan Lin $^{3}$ \\ ${ }^{1}$ Department of Accounting, and Department of Finance, Shih Chien University, Taipei, Taiwan \\ ${ }^{2}$ Department of Finance, Ming Chuan University, Taipei, Taiwan \\ ${ }^{3}$ Department of Banking and Finance, Takming University of Science and Technology, Taipei, Taiwan \\ Correspondence: Lie-Huey Wang, Department of Finance, Ming Chuan University, 250 Zhong-Shan N. Rd., Sec. \\ 5, Taipei, 11103, Taiwan. Tel: 886-2-2882-4564 ext. 2191. E-mail: lhwang@mail.mcu.edu.tw
}

Received: July 14, 2014

Accepted: August 7, 2014

Online Published: December 25, 2014

doi:10.5539/ijef.v7n1p68

URL: http://dx.doi.org/10.5539/ijef.v7n1p68

\begin{abstract}
This study uses a random effect panel model to examine the impact of CEO traits and compensation on earnings performance and financial leverage for the 729 listed US companies in ExecuComp over the period of 20012010. The results indicate that CEO cash compensation has a negative relationship with earnings performance, but that it has a positive impact on financial leverage. Moreover, for CEOs, longer tenure results in reduced earnings risk-taking for debt financing, but older CEOs generate higher earnings and increase debt capacity. In addition, it is also found that there is a negative relationship between CEO compensation and earnings for firms with poor performance. Cash compensation increases the use of debt for high leverage companies, but equity-based compensation decreases the use of debt for low leverage companies. A longer tenure and greater age also have a negative relationship with both earnings and debt financing for poor performance or low leverage companies. However, older CEOs generate more earnings and financing capacity for firms with good performance or high leverage.
\end{abstract}

Keywords: CEO traits, incentive pay-performance, financial leverage, risk-aversion

\section{Introduction}

Agency theory states that the characteristics of top management team and the compensation system are important governance variables that allow a firm to execute complicated strategies (Bantel, 1994; Krishnan, Miller, \& Judge, 1997; Sanders \& Carpenter, 1998). It suggests that the conflict of interests between the management and shareholders should be realigned via the tenure of top management team and a long-term compensation system (Burgelman, 1991; Hambrick \& D’Aveni, 1992; Melin, 1992).

Prior studies indicate that there is a correlation between corporate governance structure and CEO compensation. For example, Lippert and Moore (1995) and Fahlenbrach (2009) suggested that CEO compensation and a firm's governance structure act as substitutes, to align CEO's behavior and shareholders' interests. Therefore, within a corporate governance structure, incentive compensation is an effective method of reducing the agency problem between shareholders and the management (Mayers \& Smith, 2010; Ross, 1973; Fama \& Jensen 1983; Jensen \& Meckling, 1976; Palmon, Bar-Yosef, Chen, \& Venezia, 2008). However, there are also some empirical studies that do not support the existence of incentive pay-performance relationship for CEOs (Tosi, Werner, Katz, \& Comez-Mejia, 2000; Dalton, Daily, Certo, \& Roengpitya, 2003).

Empirical studies find that either there is a positive correlation between pay and performance (Murphy, 1985; Coughlan \& Schmidt, 1985; Core, Holthausen, \& Larcker, 1999; Brick, Palmon, \& Wald, 2006; Kato \& Kubo, 2006; Lin, Kuo, \& Wang, 2013), or that there is a low correlation, or no correlation at all (Zhou, 2000; Buck, Bruce, Main, \& Udueni, 2003; Fernandes, 2008; Duffhues \& Kabir, 2008; Shaw \& Zhang, 2010; Chang, Dasgupta, \& Hilary, 2010; Ozkan, 2011). The recent American financial crisis triggered discussion on the impact of compensation systems on the risk-taking behavior of executives. An inappropriate compensation system can lead to opportunistic behavior for a firm's decision makers, which sacrifices the interests and rights of the shareholders in order to increase their wealth. Therefore, an effective compensation system should align the interests of executives and shareholders as closely as possible and prioritize the maximization of benefits for shareholders. In other words, an appropriate compensation system should be based on performance and should not encourage risk-taking behavior. However, it is found that, in practice, CEOs' compensation is not reduced 
accordingly and they are sometimes even rewarded for risk-taking, in firms with poor performance (Shaw \& Zhang, 2010).

Many studies also suggest that the traits of top management teams, such as tenure, age and education (Alderfer, 1986; Dechow \& Sloan, 1991; Sitkin \& Pablo, 1992; Bloodgood, Sapienza, \& Almeida, 1996; Wiseman \& Gomez-Mejia, 1998; Sanders \& Carpenter, 1998; Carpenter, Sanders, \& Gregersen, 2001; Vafeas, 2003; Shen, 2003; Kaymak \& Bektas, 2008) influence the firms' decision quality, operational strategies (Simeon, 2001; Golden \& Zajac, 2001; Kuo, 2000), strategic change (Hambrick \& Mason, 1984; Grimm \& Smith, 1991; Wiersema \& Bantel, 1992), strategic dynamism (Finkelstein \& Hambrick, 1990) and risk-taking behavior (Hitt \& Tyler, 1991; Carpenter, Pollock, \& Leary, 2003).

In summary, most studies agree that $\mathrm{CEO}$ compensation and traits influence firm performance and risk-taking behavior of CEOs. Therefore, this study analyzes the impact of CEO on earnings performance and financial leverage from the angle of the performance incentives and risk avoidance behavior derived from CEO compensation and traits such as tenure and age. Thus, this study makes two main contributions to the extant literature by examining the links among CEO compensation, traits, earnings performance, and financial leverage. First, we demonstrate that a combination of CEO compensation and traits has an effect on earnings performance and financial leverage. Our results show that CEO cash compensation has a negative relationship with earnings performance, but that it has a positive impact on financial leverage. Moreover, CEOs with longer tenure do not benefit to firms' earnings but can reduce risk-taking for debt financing. Older CEOs also generate higher earnings and increase debt capacity. Second, we seek to investigate the extent to which a firm with high-pay-low-performance or low-pay-high-performance may interfere with the association between CEO cash compensation (or CEO traits), and earnings performance (or risk aversion behavior of CEOs). Our results demonstrate that there is a negative relationship between CEO compensation and earnings, for firms with poor performance. Cash compensation increases the use of debt for high leverage firms, but equity-based compensation decreases the use of debt for low leverage firms. A longer tenure and greater age also have a negative relationship with both earnings and debt financing, for poor performance or low leverage firms. However, older CEOs generate more earnings and financing capacity for high performing or high leverage firms.

The remainder of this paper is organized as follows. Section 2 discusses the relevant prior literature for performance incentives for CEO compensation and risk avoidance due to CEO traits, as the foundation for this study. Section 3 describes the data source, the variable measurements and the specifications of the empirical models. Section 4 provides details of the empirical results and discusses the results of the study. Section 5 offers a brief summary and concluding remarks.

\section{Literature Review and Hypothesis Development}

\subsection{Incentive Pay-Performance}

The evaluation of compensation for top management, based on firm performance, has a basis in logic and theory. Jensen and Murphy (1990) analyzed the correlation between performance and compensation for top management and the results show that incentive compensation does not seem to work as expected. In practice, compensation for top management includes base salary, benefits, perquisites, short-term incentives and long-term incentives. Of these, base salary is externally competitive (Miller, 1995), while incentive compensation influences CEO behaviors (Bergmann \& Scarpello, 2002). Ross (1973), Jesen and Meckling (1976), Palmon et al. (2008) and Mayers and Smith (2010) demonstrated that incentive compensation is an important internal governance mechanism that aligns the conflicts of interests between shareholders and the management. Core et al. (1999), Brick et al. (2006) and Kato and Kubo (2006) found that CEO compensation and firm performance are significantly positively correlated. Abowd (1990) also found that making a stronger link between CEO compensation and performance can help to increase a firm's profitability or equity return.

Hill and Phan (1991) suggested that linking CEO pay to risk fulfills the CEO's private interest, because higher risk for the firm increases the probability of losing their job, so they demand higher compensation as a safeguard. Berger, Ofek, and Yermack (1997) and Coles, Daniel, and Naveen (2006) used cash compensation as the proxy variable for $\mathrm{CEO}$ risk aversion and found that higher cash compensation is reflected in a greater aversion to risk for CEOs. Many studies show that a higher correlation between CEO equity compensation and performance increases risk-taking behavior in CEOs (Knopf, Nam, \& Thornton, 2002; Chen, Steiner, \& Whyte, 2006; Brockman, Martin, \& Unlu, 2010), so it could increase the financial risk associated with the firm's investment decisions (Coles et al., 2006), generate inefficient investments (Titman, Wei, \& Xie, 2004; Balachandran \& Mohanram, 2010), cause the CEOs to engage in risky mergers (Datta, Iskandar-Datta, \& Raman, 2001), encourage the CEO to follow personal agency interests by increasing the firm's debts (Mehran, 1992; Berger et 
al., 1997), or increase risk-taking by adopting a suboptimal capital structure (Dong, Wang, \& Xie, 2010). However, Lewellen (2006) and Tchistyi, Yermack, and Yun (2011) found that a firm's debt increases the volatility of stock prices and the risk costs of managers who avert risk, so equity-based compensation does not encourage the manager to increase financial leverage. In addition, Berger et al. (1997) found that a low correlation between CEO pay and performance can discourage the use of high financial leverage. Carpenter (2000) and Ross (2004) did not find a significant correlation between equity-based compensation and risk-taking behavior. However, Hallock, Madlozzo, and Reck (2010) showed that the differences in CEOs' ability, risk aversion and firm risks are possible fundamental sources of heterogeneity in the pay-for-performance relationship.

In summary, numerous studies argue that the cash compensation may not be sufficient to motivate CEOs thereby it is not punished for poor firm performance. This implies a negative relationship between cash compensation and performance. In addition, higher cash compensation will discourage CEOs to increase risk-taking behavior which will erode their interests. Therefore, firms pay the higher cash compensation to CEOs will induce CEOs to disapprove of debt financing. Based on these findings, we propose the following hypothesis:

H1: There is a negative association between cash compensation and earnings performance, but there is a positive association between cash compensation and risk aversion behavior of CEOs.

\subsection{Risk Aversion as a CEO Traits}

Bertrand and Schoar (2003) showed that CEO managerial style affects corporate behavior and results in heterogeneity in firm performance. Simeon (2001) suggested that the traits of top management (such as tenure, age and educational background) are important corporate governance variables that affect a firm's specialization, diversification and internationalization. Golden and Zajac (2001) and Kuo (2000) found that a firm's operational strategy and strategic changes are affected by the traits of top management. Cole et al. (2006) and Chava and Puranandam (2010) noted that a firm's financial decisions are significantly influenced by the incentives for the CEO to take risks.

Prior studies address that CEO tenure and age are important factors that impact a firm's managerial efficiency. In terms of CEO tenure, Jensen and Meckling (1979) contended that shorter tenure for managers can increase the number of hurdles for investment plans, resulting into underinvestment. Finkelstein and Hambrick (1990) found that top manager tenure and strategic persistence are positively correlated. Hambrick and Fukutomi (1991) and Hambrick, Geletkanycz, and Fredrickson (1993) suggested that CEOs with longer tenure show more commitment to the organizational status quo and less willingness to promote innovation and technological improvement. In terms of CEO age, Hambrick and Mason (1984), Grimm and Smith (1991) and Wiersema and Bantel (1992) found that the age of top manager is negatively correlated with a firm's strategic changes. Eisenhardt and Schoonhoven (1990) documented that older management teams prefer to maintain the status quo, so employing younger management teams in industries with higher environmental variability allows a firm to adapt to the impact of environmental shifts and improve managerial performance. Hitt and Tyler (1991) demonstrated that the age of a manager and his risk preference are negatively correlated. Alderfer (1986) proposed that less experienced top management teams require more time to become familiar with the operation of the firm, which results in poor efficiency. In contrast, Wiseman and Gomez-Mejia (1998) and Sitkin and Pablo (1992) noted that older and more experienced CEOs increase firm performance and reduce firm risk.

Antia, Pantzalis, and Park (2010) addressed that CEOs with longer tenure or older age have long-term decision horizons. They used CEO tenure and age as proxy variables for decision horizons and found that CEOs with a myopic decision horizon cause higher agency costs, lower firm value and higher information risk. However, Ryan and Wiggins (2001) found that CEOs who are older or who have longer tenure have more chance to engage in opportunistic behavior out of self-interest, because they have accumulated more power and influence. In other words, this finding supports the entrenchment hypothesis.

Overall, existing empirical evidence largely suggests that CEOs with longer tenure or older age are more commitment to status quo and have more experience thus leading to poor performance. However, they may be more conservative about debt financing. Accordingly, we posit following hypotheses:

H2: There is a negative association between CEOs' tenure and earnings performance, but there is a positive association between tenure and risk aversion behavior of CEOs.

H3: There is a negative association between CEOs' age and earnings performance, but there is a positive association between age and risk aversion behavior of CEOs. 


\section{Data and Empirical Model}

\subsection{Data}

The panel data for the 729 listed US firms for the period of 2001-2010 is used for the empirical study. The data are from the ExecuComp database. The full sample comprises 34 mining firms, 11 construction firms, 336 manufacturing firms, 102 transport, transportation, utility and health industry firms, 22 wholesale firms, 59 retail trading firms, 98 finance, insurance and real-estate firms and 79 service firms.

The empirical variables include earnings performance, financial leverage, CEO compensation, CEO traits, firm characteristics, industry category and financial crisis. For earnings performance and financial leverage, the return on assets (ROA) and return on equity (ROE) are used as proxies to measure a firm's total return and shareholder return and the debt ratio is used as a proxy to measure a firm's financial leverage. In terms of CEO compensation, Murphy (1999) showed that cash compensation for CEOs and performance are not significantly related. Ozkan (2011) noted that cash compensation and performance are significantly positively correlated. Hall and Liebman (1998) also found that there is a significant correlation between equity-based compensation and firm performance. Therefore, CEO compensation is divided into cash compensation and equity-based compensation. Cash compensation, including base salary and bonus, is a fixed compensation that is related to a firm characteristic, industry category, CEO background and short-term incentives. In this study, it is measured by the ratio of cash-payouts to total compensation. Equity-based compensation, including stock options (evaluated by Black-Scholes model), stock dividends and long-term incentive compensation plans, is a variable compensation. It is measured by deducting cash payouts from total compensation and then the ratio of this amount to total compensation is used. The variables for CEO traits include tenure, age, CEO change times, gender, duality and directorship. For CEO tenure, the years the CEO has been the CEO are calculated. For CEO age, each CEO was checked by name and any errors that might have been in the database were corrected. For CEO change times, the tenure of each CEO was used to calculate the change times for each company, from 2001 to 2010. In terms of firm characteristics, company size and growth opportunities were considered. Total assets are used as a proxy for firm size and market value ratio as a proxy for growth opportunities (Core \& Guay, 1999; Leone, Wu, \& Zimmerman, 2006; Carter, Lynch, \& Tuna, 2007; Shaw \& Zhang, 2010; Bulan, Sanyal, \& Yan, 2010; Ozkan, 2011). For the industry category, the first two digits of the SIC code are used to divide the sample. SIC codes 01 to 09 are agriculture, forestry and fishing industries; 10 to 14 are for the mining industry; 15 to 17 are for the construction industry; 20 to 39 are for the manufacturing industry; 40 to 49 are transportation, communications, electric, gas and sanitary service industries; 50 to 51 are for the wholesale trade industry; 52 to 59 are for the retail trade industry; 60 to 67 are for finance, insurance and real estate industries and 70 to 89 are for services industries. Dummy variables are used to control the effect of industries. Finally, the empirical models also include a financial crisis dummy variable, using the year end in 2007 as the critical time. The definition of each variable is listed in Table 1.

\subsection{Empirical Model}

Given the cross-sectional and time-series data, a panel data regression model is used in this study. Firstly, for the earnings performance model, the dependent variable is ROE (or ROA) and the independent variables are CEO compensation and traits. In addition, the factors that used as control variables include firm size, growth opportunity, financial leverage and industry category. The empirical model is as shown in equation (1):

$$
\begin{gathered}
\text { Performance }_{i t}=\alpha_{i}+\beta_{1} \text { Cash }_{i t}+\beta_{3} \text { Hucash }_{i t} \times \text { Cash }_{i t}+\beta_{3} T \times \text { Hcash }_{i t} \\
+\beta_{4} \text { SizeD }_{i t} \times \text { Hcash }_{i t}+\beta_{5} \text { Tenure }_{i t}+\beta_{6} \text { Age }_{i t}+\beta_{7} \text { LnTA }_{i t} \\
+\beta_{8} \text { MBratio }_{i t}+\beta_{9} \text { Debtratio }_{i t}+\beta_{10} \text { SICdummy }_{i}+\varepsilon_{i t}
\end{gathered}
$$

Secondly, for the financial leverage model, the dependent variable is debt ratio and the independent variables are CEO compensation and traits. The other controlled variables include firm size, growth opportunity, profitability and industry category. The empirical model is as shown in equation (2):

$$
\begin{aligned}
\text { Debtratio }_{i t} & =\alpha_{i}+\beta_{1} \text { Cash }_{i t}+\beta_{3} \text { Hucash }_{i t} \times \text { Cash }_{i t}+\beta_{3} T \times \text { Hcash }_{i t} \\
& +\beta_{4} \text { SizeD }_{i t} \times \text { Hcash }_{i t}+\beta_{5} \text { Tenur }_{i t}+\beta_{6} \text { Age }_{i t}+\beta_{7} \text { LnTA }_{i t} \\
& +\beta_{8} \text { MBratio }_{i t}+\beta_{9} \text { ROA }_{i t}+\beta_{10} \text { SICdummy }_{i}+\varepsilon_{i t}
\end{aligned}
$$

In equations (1) and (2), Performance ${ }_{i t}$ is the firm's earnings performance, which is measured by ROE or ROA. Debtratio $_{i t}$ is the firm's financial leverage, using debt ratio as the proxy. Since the correlation coefficient for cash compensation and equity-based compensation is -1 (as subsequent Pearson correlation coefficient tests show), the model only includes the cash compensation ratio. Cash $_{i t}$ is the CEO cash compensation ratio. For CEO trait 
variables, since there is high homogeneity between gender, position duality and directorship, and since CEO change and CEO tenure are highly negatively correlated, only CEO tenure and age variables are included in the model. $L n T A_{i t}$ is a firm size variable, calculated by taking the natural logarithm of total assets (LnTA) as the measurement variable. MBratio $i t$ is the firm's growth opportunity, which uses market-to-book ratio as the proxy. SICdummy is $_{i}$ the industry dummy variable.

In order to further determine whether there is any interaction in the correlation between incentive compensation and pay-for-performance (or pay-for-debt), the interaction item of Hucash $\times$ Cash is also included. Hucash $=1$, if the equity-based compensation ratio for the firm is higher than the median of the equity-based compensation ratio for all variables; otherwise, Hucash $=0$. Since the cash compensation ratio and equity-based compensation ratio are highly negatively correlated, Hucash $\times$ Cash is multiplied by -1 .

Table 1. Definition of variables

\begin{tabular}{|c|c|}
\hline Variable & Definition \\
\hline \multicolumn{2}{|l|}{ Earnings performance } \\
\hline Return on equity (ROE) & Return on equity $=($ Net income after tax $\div$ Average shareholder equity book value $) \times 100 \%$. \\
\hline Return on assets (ROA) & Return on assets $=($ Net income after tax $\div$ Average total assets $) \times 100 \%$ \\
\hline \multicolumn{2}{|l|}{ Financial leverage } \\
\hline Debt ratio (Debtratio) & Debt ratio $=($ Total debts $\div$ Total assets $) \times 100 \%$ \\
\hline \multicolumn{2}{|l|}{ CEO compensation } \\
\hline Cash compensation ratio (Cash) & Cash compensation ratio $=[($ Salary + Bonus $) \div$ Total compensation $] \times 100 \%$ \\
\hline $\begin{array}{l}\text { Equity-based compensation ratio } \\
\text { (Ucash) }\end{array}$ & $\begin{array}{l}\text { Equity-based compensation ratio }=[\text { (Total compensation-Cash compensation) } \div \text { Total } \\
\text { compensation }] \times 100 \% \text {. Equity-based compensation includes stock option (evaluated by }\end{array}$ \\
\hline Cash compensation dummy (Hcash) & $\begin{array}{l}\text { Black-Scholes model), stock dividend, and long-term incentives. } \\
\text { Hcash }=1 \text {, if the firm's cash compensation ratio is higher than the median of the cash } \\
\text { compensation ratio for all samples; otherwise, Hcash }=0 \text {. }\end{array}$ \\
\hline $\begin{array}{l}\text { Equity-based compensation dummy } \\
\text { (Hucash) }\end{array}$ & $\begin{array}{l}\text { Hucash }=1 \text {, if the firm's equity-based compensation ratio is higher than the median of the } \\
\text { equity-based compensation ratio for all samples; otherwise, Hucash }=0 \text {. }\end{array}$ \\
\hline \multicolumn{2}{|l|}{ CEO traits } \\
\hline CEO tenure (Tenure) & CEO tenure $=$ years being the CEO \\
\hline CEO age (Age) & $\mathrm{CEO}$ age $=$ the age of the CEO. \\
\hline CEO change (Change) & $\begin{array}{l}\text { Check the starting time for each CEO and calculate the times each company has changed its } \\
\text { CEO from } 2001 \text { to } 2010 \text {. }\end{array}$ \\
\hline CEO gender (Gender) & Male $=1 ;$ otherwise, female $=0$ \\
\hline CEO duality (Duality) & $\begin{array}{l}\text { CEO duality }=1 \text {, if the CEO is also the chairman of the board, the president, or the general } \\
\text { manager }=1 \text {; otherwise, CEO duality }=0 \text {. }\end{array}$ \\
\hline CEO directorship (CEODIR) & CEO directorship $=1$, if the CEO is also a director; otherwise CEO directorship $=0$ \\
\hline \multicolumn{2}{|l|}{ Firm characteristics } \\
\hline Firm size (TA, LnTA, SizeD) & $\begin{array}{l}\text { The firm size variable contain two proxy, one is total assets size (LnTA) = take the natural } \\
\text { logarithm of total assets, the other is firm size dummy (SizeD), SizeD }=1 \text {, if the firm's total } \\
\text { assets is greater than the median of the total assets of all samples; otherwise, SizeD }=0 \text {. }\end{array}$ \\
\hline Growth opportunity (MBratio) & $\begin{array}{l}\text { Market-to-book ratio }=\text { market value of the shareholders' equity at the end of the year } \div \text { book } \\
\text { value of the shareholder's equity at the end of the year. }\end{array}$ \\
\hline Industry category (SICdum) & $\begin{array}{l}\text { The first two digits of SIC codes are used to divide the sample. SIC codes } 01 \text { to } 09 \text { are } \\
\text { agriculture, forestry and fishing industries; } 10 \text { to } 14 \text { is mining industry; } 15 \text { to } 17 \text { is construction } \\
\text { industry; } 20 \text { to } 39 \text { is manufacturing industry; } 40 \text { to } 49 \text { are transportation, communications, } \\
\text { electric, gas and sanitary service industries; } 50 \text { to } 51 \text { is wholesale trade industry; } 52 \text { to } 59 \text { is } \\
\text { retail trade industry; } 60 \text { to } 67 \text { are finance, insurance and real estate industries; and } 70 \text { to } 89 \text { is } \\
\text { services industry. The industry categories are measured by } 7 \text { industry dummy variables. }\end{array}$ \\
\hline Financial crisis $(\mathrm{T})$ & The year end in 2007 is used as the critical time; before $2007, \mathrm{~T}=0$; otherwise, $\mathrm{T}=1$. \\
\hline
\end{tabular}

After the 2007 American financial crisis triggered discussion of the impact of compensation on the risk-taking behavior of decision makers, some firms have adjusted their compensation structure due to public opinion. Therefore, in order to determine whether pay-for-performance (or pay-for-debt) is influenced by the 2007 American financial crisis, an interaction item, $T \times H c a s h$, is used in the model. Hcash=1, if the cash 
compensation ratio for the firm is higher than the median of the cash compensation ratio of all samples; otherwise, $H c a s h=0$. T is the dummy variable for the financial crisis. Before 2007, $T=0$; otherwise, $T=1$.

Finally, the models also take into account that compensation in larger firms is generally higher than that in smaller firms, so the interaction item, SizeD $\times$ Hcash is included. SizeD=1, if the firm's total assets is larger than the median of the total assets for all of the sample firms; otherwise, $\operatorname{Size}=0$.

\section{Empirical Results}

\subsection{Descriptive Statistics}

Table 2 shows the descriptive statistic for all of the variables used in the regressions. Overall, the mean and median of the ROE for the 729 firms are higher than the mean and median of the ROA, which shows that return on equity for shareholders is higher than the return on assets for the firms. In terms of CEO compensation, the medians of the cash compensation ratio and the equity-based compensation ratio are $31.12 \%$ and $68.88 \%$, respectively. This indicates that most firms use incentive-based variable compensation for a CEO. In terms of CEO traits, the mean CEO tenure is 6 years; the range of the CEO age is from 30 to 83, but mostly it is 56 to 57 . It is also seen that 232 firms did not change their CEOs, 396 firms changed their CEO once, 87 firms changed their CEO twice, 10 firms changed their CEO three times and 4 firms changed their CEO four times, which shows that in most of the firms a CEO has stable tenure. In terms of CEO gender, $98 \%$ of the CEOs are male, $94 \%$ have dual positions and $98 \%$ of the CEOs are also board directors. Since the CEOs of the 729 firms have stable tenure, $94 \%$ of the CEOs are male and most of them hold dual positions, the subsequent analysis only includes CEO tenure and age variables.

Table 2. Descriptive statistics

\begin{tabular}{lllll}
\hline Variable & Mean & Median & Minimum & Maximum \\
\hline ROE (\%) & 11.01 & 12.05 & -231.91 & 262.89 \\
ROA (\%) & 4.08 & 4.40 & -263.07 & 55.45 \\
Debt ratio(\%) & 55.20 & 56.42 & 2.49 & 99.36 \\
Cash (\%) & 38.44 & 31.12 & 0.12 & 100.00 \\
Ucash (\%) & 61.55 & 68.88 & 0.00 & 99.88 \\
Tenure & 7.8 & 6 & 0.3 & 48.0 \\
Age & 56 & 56 & 30 & 83 \\
Change & 0.84 & 1 & 0 & 4 \\
Gender & 0.98 & 1 & 0 & 1 \\
Duality & 0.94 & 1 & 0 & 1 \\
CEODIR & 0.98 & 1 & 0 & 1 \\
TA (million USD) & 17788 & 2744 & 29 & 2175052 \\
MBratio (times) & 2.72 & 2.09 & 0.08 & 80.56 \\
\hline
\end{tabular}

Note. $\mathrm{ROE}=($ net income after tax $\div$ average shareholder equity book value $) \times 100 \%$. ROA $=($ net income after tax $\div$ average total assets $) \times 100 \%$. Debtratio $=$ (total debt $\div$ total assets $) \times 100 \%$. Cash is cash compensation ratio $=[($ salary + bonus $) \div$ total compensation $] \times 100 \%$. Ucash is equity-based compensation ratio $=[$ (total compensation-cash compensation $) \div$ total compensation $] \times 100 \%$. Tenure is the years the CEO has been the CEO. Age is the age of the CEO in years. Change is the times the firm has changed the CEO between 2001 and 2010 . Gender=1, if CEO is male; otherwise, Gender $=0$. Duality $=1$, if CEO is also the chairman of the board, the president, or the general manager; otherwise, Duality $=0$. CEODIR $=1$, if CEO is also a director, otherwise, CEODIR $=0$. TA is the total assets the firm has at the end of the year. MBratio is market value of the shareholders' equity at the end of the year $\div$ book value of the shareholder's equity at the end of the year.

\subsection{Correlation Analysis}

A Pearson correlation coefficient analysis is used to test the correlation between the variables. Table 3 shows the result of the Pearson correlation coefficient test. The results show that the cash compensation ratio and the equity-based compensation ratio have a significantly negatively correlation, so the subsequent analysis only includes the cash compensation ratio variable in the empirical models. In terms of compensation-performance correlation, cash compensation and earnings performance (measured by ROA and ROE) are significantly negatively correlated, but equity-based compensation and earnings performance are significantly positively correlated, which demonstrates that cash compensation is an insufficient incentive for earnings performance, but equity-based compensation is an incentive to increasing earnings performance. In addition, in terms of the relationship between CEO traits and earnings performance or financial leverage, CEO tenure and debt ratio are 
significantly negatively correlated, which shows that CEOs with longer tenure have a high aversion to risk and prefer lower financial leverage. CEO duality and debt ratio are significantly positively correlated, which shows that CEOs with dual positions can cause debt-agency problems, or if they have more power to control the firm's risk, this can increase the firm's debt capacity. Finally, in terms of the correlation between CEO traits and compensation, the cash-compensation ratio is significantly positively correlated with both CEO tenure and age, but the equity-based compensation ratio is significantly negatively correlated with CEO tenure and age, which shows that firms with shorter $\mathrm{CEO}$ tenure or younger CEOs have a higher equity-based compensation ratio; that is, firms with these $\mathrm{CEO}$ traits prefer a greater link between compensation and performance.

\subsection{Difference Analysis}

Firstly, a one-way ANOVA determines whether the means of the variables for each industry are different and the results are presented in Table 4. The F-test of the one-way ANOVA indicates that, overall, the earnings performance, financial leverage, CEO compensation, CEO traits and firm characteristics for the eight industries are all significantly different. In addition, in terms of CEO compensation, the construction, transportation/utility/sanity and wholesale industries prefer cash-compensation, whereas the mining, manufacturing, retail, finance and real estate, and service industries prefer equity-based compensation. In terms of CEO traits, the construction industries have longer CEO tenure (11.42 years).

Secondly, a two sample t-test is used to test for a difference in a high/low cash compensation ratio, large/small firm size and before/after the 2007 financial crisis. The results are presented in Panel A of Table 5. The results for a high/low cash compensation ratio indicate that firms with a higher cash compensation ratio have a significantly lower ROE, ROA, total assets size, market-to-book ratio and debt ratio. However, CEO tenure and CEO age are significantly higher. The results for large/small firm size indicate that larger firms have a significantly higher equity-based compensation ratio than smaller firms, which shows that larger firms prefer equity-based compensation and the linkage between CEO pay and performance. The CEO tenure for larger firms is also shorter and the CEO age in larger firms is higher than that in smaller firms, which indicates that larger firms prefer to hire more experienced CEOs. Finally, the ROE, ROA, assets size, market-to-book value and debt ratio for larger firms are significantly higher than those for smaller firms. The results for before/after 2007 financial crisis show that, after 2007, the cash compensation ratio decreases and the equity-based compensation ratio increases, which indicates that, after the financial crisis, firms are more concerned with the linkage between CEO pay and firm performance. It is also found that the debt ratio increases, but the ROE, ROA and market-to-book ratio significantly decrease.

Finally, a two sample t-test is also used to determine the difference for high/low earnings performance and financial leverage. The results are presented in Panel B of Table 5. The result shows that, in terms of CEO's compensation, firms with a higher ROE, ROA and debt ratio have a higher equity-based compensation ratio. In terms of CEO traits, firms with a higher ROA have longer CEO tenure, while firms with higher debt have shorter $\mathrm{CEO}$ tenure and older CEOs. This shows that there is a possible connection between equity-based compensation, performance and debt. It is also found that there is a high debt-high ROE and a high debt-low ROA relationship. Whether this phenomenon is influenced by the firm's manipulation of financial leverage or the CEO's risk-taking behavior in using high financial leverage for self-interest remains to be determined.

\subsection{Estimated Results of Random-Effect Panel Model}

This study uses a random effect panel model for the empirical analysis. The result is presented in Table 6 . Overall, CEO cash compensation and earnings performance (measured by ROE and ROA) are negatively correlated, which indicates that fixed cash payment can cause a CEO favor the status quo. This is insufficient as incentive to increase firm performance and has a lower linkage with firm performance. Therefore, a higher ratio of fixed pay in the compensation structure is not beneficial to the firm's earnings performance. Equity-based compensation is a variable payment and there is a direct linkage to performance, so a higher ratio of variable payment has a greater linkage with the firm's earnings performance. This result corresponds with the findings of Core et al. (1999), Brick et al. (2006) and Kato and Kubo (2006). 
Table 3. Pearson correlation test

\begin{tabular}{|c|c|c|c|c|c|c|c|c|c|}
\hline Variable & ROE & ROA & Debtratio & Cash & Ucash & Tenure & Age & LnTA & MBratio \\
\hline ROE & 1 & & & & & & & & \\
\hline ROA & $0.791 * * *$ & 1 & & & & & & & \\
\hline Debtratio & $0.053 * * *$ & $-0.149 * * *$ & 1 & & & & & & \\
\hline Cash & $-0.104 * * *$ & $-0.065 * * *$ & $-0.087 * * *$ & 1 & & & & & \\
\hline Ucash & $0.104 * * *$ & $0.065^{* * *}$ & $0.087 * * *$ & $-1.000 * * *$ & 1 & & & & \\
\hline Tenure & -0.017 & -0.003 & $-0.112 * * *$ & $0.161 * * *$ & $-0.161 * * *$ & 1 & & & \\
\hline Age & $0.023 * *$ & 0.017 & $0.061 * * *$ & $0.049 * * *$ & $-0.049 * * *$ & $0.438 * * *$ & 1 & & \\
\hline LnTA & $0.124^{* *}$ & $0.034 * * *$ & $0.571 * * *$ & $-0.309 * *$ & $0.309 * *$ & $-0.125 * *$ & $0.093 * *$ & 1 & \\
\hline MBratio & $0.427 * * *$ & $0.280 * * *$ & $0.023 * * *$ & $-0.082 * * *$ & $0.082 * * *$ & -0.002 & $-0.035 * * *$ & $-0.051 * *$ & 1 \\
\hline
\end{tabular}

Note. $\mathrm{ROE}=($ net income after tax $\div$ average shareholder equity book value $) \times 100 \%$. ROA $=$ (net income after tax $\div$ average total assets $) \times 100 \%$. Debtratio $=$ (total debt $\div$ total assets $) \times 100 \%$. Cash is cash compensation ratio $=[($ salary+bonus $) \div$ total compensation $] \times 100 \%$. Ucash is equity-based compensation ratio $=[$ (total compensation-cash compensation $) \div$ total compensation $] \times 100 \%$. Tenure is the years the CEO has been the CEO. Age is the age of the CEO in years. LnTA is the natural logarithm of total assets the firm has at the end of the year. MBratio is market value of the shareholders'equity at the end of the year $\div$ book value of the shareholder's equity at the end of the year. Statistical significance is denoted by $* * *$ and $* *$ for $1 \%$ and $5 \%$ levels, respectively.

Table 4. One-way ANOVA test

\begin{tabular}{llllllllll}
\hline Industry & ROE & ROA & Debtratio & Cash & Ucash & Tenure & Age & TA & MBratio \\
\hline Mining & $8.48 \mathrm{a}$ & 4.44 & 49.90 & $35.26 \mathrm{a}$ & 64.73 & 8.36 & 56.59 & $7,635.62$ & 2.32 \\
Construction & 11.73 & 4.36 & 52.89 & 41.23 & 58.76 & 11.42 & 56.14 & $3,012.77$ & 1.97 \\
Manufacturing & 10.08 & 4.06 & 48.40 & 37.71 & 62.28 & 7.53 & 56.04 & $7,502.73$ & 2.91 \\
Transportation, & 10.44 & 3.27 & 66.80 & 40.67 & 59.32 & 7.82 & 57.24 & $17,032.71$ & 2.00 \\
Communication, & & & & & & & & & \\
Utility, and Sanitary & & & & & & & & \\
Wholesale & 10.78 & 4.31 & 58.56 & 41.39 & 58.60 & 7.51 & 54.70 & $4,318.19$ & 2.31 \\
Retail Trade & 14.19 & 7.01 & 47.29 & 38.15 & 61.84 & 7.42 & 55.63 & $8,457.99$ & 2.84 \\
Finance, Insurance, & 12.02 & 2.45 & 78.47 & 38.71 & 61.28 & 8.08 & 56.64 & $80,107.61$ & 2.33 \\
and Real-estate & & & & & & & & \\
Service & 13.36 & 4.76 & 48.79 & 38.73 & 61.26 & 8.72 & 55.30 & $5,176.77$ & 3.72 \\
F-test & $5.44 * * *$ & $13.59^{* * *}$ & $382.65^{* * *}$ & $2.78^{* * *}$ & $2.78^{* * *}$ & $7.26^{* * *}$ & $8.72 * * *$ & $102.29 * * *$ & $31.26^{* * *}$ \\
\hline
\end{tabular}

Note. $\mathrm{ROE}=($ net income after tax $\div$ average shareholder equity book value $) \times 100 \%$. ROA $=$ (net income after tax $\div$ average total assets $) \times 100 \%$. Debtratio $=($ total debt $\div$ total assets $) \times 100 \%$. Cash is cash compensation ratio $=[($ salary+bonus $) \div$ total compensation $] \times 100 \%$. Ucash is equity-based compensation ratio $=[$ (total compensation-cash compensation $) \div$ total compensation $] \times 100 \%$. Tenure is the years the CEO has been the CEO. Age is the age of the CEO in years. TA is the total assets the firm has at the end of the year. MBratio is market value of the shareholders' equity at the end of the year -book value of the shareholder's equity at the end of the year. Statistical significance is denoted by $* * *$ for $1 \%$ level.

\section{Table 5. Two sample t-test}

Panel A. Cash compensation, firm size, and financial crisis

\begin{tabular}{|c|c|c|c|c|c|c|c|c|c|}
\hline \multirow{2}{*}{ Variable } & \multicolumn{3}{|c|}{ Cash compensation } & \multicolumn{3}{|c|}{ Firm size } & \multicolumn{3}{|c|}{ Financial crisis } \\
\hline & High & Low & t-test & Large & Small & $\mathrm{t}$-test & Before 2007 & After 2007 & $\mathrm{t}$-test \\
\hline \multicolumn{10}{|c|}{$\begin{array}{l}\text { Performance } \\
\text { and leverage }\end{array}$} \\
\hline ROE & $9.50 \S$ & 12.50 & $-6.192 * * *$ & 13.20 & 8.80 & $9.081 * * *$ & 11.76 & 9.87 & $3.663 * * *$ \\
\hline ROA & 3.59 & 4.57 & $-4.398 * * *$ & 4.25 & 3.91 & 1.516 & 4.40 & 3.59 & $3.502 * * *$ \\
\hline \multicolumn{10}{|c|}{$\begin{array}{l}\text { CEO } \\
\text { compensation }\end{array}$} \\
\hline Cash & 58.99 & 18.17 & $106.563 * * *$ & 31.48 & 45.43 & $-23.674 * * *$ & 45.08 & 28.48 & $29.084 * * *$ \\
\hline Ucash & 41.01 & 81.83 & $-106.563 * * *$ & 68.52 & 54.56 & $23.674 * * *$ & 54.92 & 71.52 & $-29.084 * * *$ \\
\hline CEOtraits & & & & & & & & & \\
\hline
\end{tabular}




\begin{tabular}{llllllllll}
\hline Tenure & 8.51 & 7.19 & $7.913 * * *$ & 7.18 & 8.51 & $-7.945 * * *$ & 7.79 & 7.93 & -0.840 \\
Age & 56.44 & 55.89 & $3.493 * * *$ & 56.51 & 55.82 & $4.464 * * *$ & 56.01 & 56.40 & $-2.524 * *$ \\
$\begin{array}{l}\text { Firm } \\
\text { characteristics }\end{array}$ & & & & & & & & & \\
TA & 14020 & 21505 & $-3.973 * * *$ & 34402 & 1092 & $18.090 * * *$ & 14882 & 22146 & $-3.417 * * *$ \\
MBratio & 2.50 & 2.95 & $-6.953 * * *$ & 2.64 & 2.80 & $-2.418 * *$ & 2.92 & 2.43 & $7.440 * * *$ \\
\hline
\end{tabular}

Panel B. High/low earnings performance and debt

\begin{tabular}{|c|c|c|c|c|c|c|c|c|c|}
\hline \multirow{2}{*}{ Variable } & \multicolumn{3}{|l|}{ ROE } & \multicolumn{3}{|l|}{ ROA } & \multicolumn{3}{|c|}{ Debtratio } \\
\hline & High & Low & t-test & High & Low & t-test & High & Low & t-test \\
\hline \multicolumn{10}{|c|}{ Performance and leverage } \\
\hline ROE & 22.34 & -0.30 & $55.593^{* * *}$ & 20.92 & 1.12 & $46.368 * * *$ & 11.89 & 10.12 & $3.642 * * *$ \\
\hline ROA & 8.60 & -0.43 & $45.823 * * *$ & 9.26 & -1.08 & $54.963 * * *$ & 2.85 & 5.31 & $-11.022 * * *$ \\
\hline Debtratio & 56.49 & 53.92 & $5.207 * * *$ & 47.36 & 63.03 & $-34.095 * * *$ & 72.34 & 38.08 & $118.205^{* * *}$ \\
\hline \multicolumn{10}{|c|}{ CEO compensation } \\
\hline Cash & 35.74 & 41.14 & $-8.884 * * *$ & 36.33 & 40.54 & $-6.899 * * *$ & 36.65 & 40.24 & $-5.886^{* * *}$ \\
\hline Ucash & 64.26 & 58.86 & $8.884 * * *$ & 63.67 & 59.46 & $6.899 * * *$ & 63.35 & 59.76 & $5.886^{* * *}$ \\
\hline \multicolumn{10}{|l|}{ CEOtraits } \\
\hline Tenure & 7.76 & 7.93 & -1.024 & 8.00 & 7.69 & $1.846^{*}$ & 7.18 & 8.51 & $-7.977 * * *$ \\
\hline Age & 56.26 & 56.07 & 1.183 & 56.12 & 56.21 & -0.609 & 56.38 & 55.95 & $2.701 * * *$ \\
\hline \multicolumn{10}{|c|}{ Firm characteristics } \\
\hline $\mathrm{TA}$ & 18895 & 16683 & 1.172 & 9094 & 26462 & $-9.269 * * *$ & 29791 & 5792 & $12.861 * * *$ \\
\hline MBratio & 3.60 & 1.84 & $28.218 * * *$ & 3.54 & 1.91 & $25.913 * * *$ & 2.75 & 2.70 & 0.815 \\
\hline
\end{tabular}

Note. This study uses the median of ROE, ROA, Debt ratio, CEO cash compensation ratio, and total assets for whole samples as the basis for dividing the samples into high/low groups. $\mathrm{ROE}=($ net income after tax $\div$ average shareholder equity book value $) \times 100 \%$. $\mathrm{ROA}=($ net income after tax $\div$ average total assets $) \times 100 \%$. Debtratio $=($ total debt $\div$ total assets $) \times 100 \%$. Cash is cash compensation ratio $=[($ salary + bonus $) \div$ total compensation $] \times 100 \%$. Ucash is equity-based compensation ratio=[(total compensation-cash compensation $) \div$ total compensation $] \times 100 \%$. Tenure is the years the CEO has been the CEO. Age is the age of the CEO in years. TA is the total assets the firm has at the end of the year. MBratio is market value of the shareholders' equity at the end of the year $\div$ book value of the shareholder's equity at the end of the year. $\S$ indictes the mean. Statistical significance is denoted by $* * *, * *$ and $*$ for $1 \%, 5 \%$, and $10 \%$ levels, respectively.

CEO cash compensation and the debt ratio also have a positive correlation, which indicates that fixed or guaranteed cash compensation reduces the CEO's sensitivity to the financial risk incurred by debt financing and can have a positively reinforcing effect on debt financing. This result is different from those of Berger et al. (1997) and Cole et al. (2006), which found that cash compensation and risk avoidance are positively correlated. However, since debt financing can increase the bankruptcy risk and is not beneficial to the future value of equity-based compensation, it can inhibit the CEO's risk-taking behavior and decrease the firm's debt financing. This result is consistent with those of Lewellen (2006) and Tchistyi et al. (2011).

Table 6. Results of random-effect panel model

Panel A. All samples

\begin{tabular}{llll}
\hline Variable & ROE & ROA & Debtratio \\
\hline Intercept & $-11.4199^{* * *}$ & -2.3109 & $11.8092^{* * *}$ \\
Cash & $-0.0478^{* * *}$ & $-0.1260^{* *}$ & $0.0273^{* * *}$ \\
Hucash $\times$ Cash & $0.0803^{* * *}$ & $0.0278^{* *}$ & -0.0154 \\
T $\times$ Hcash & $-5.6468^{* * *}$ & $-2.3188^{* * *}$ & 0.4726 \\
SizeD $\times$ Hcash & $1.4006^{*}$ & 0.3972 & 0.2845 \\
Tenure & -0.0095 & $-0.0404^{*}$ & $-0.0670^{* *}$ \\
Age & $0.0836^{*}$ & $0.0565^{* * *}$ & 0.0343 \\
LnTA & $2.6653^{* * *}$ & $1.3890^{* * *}$ & $3.6420^{* * *}$ \\
Mbratio & $2.3492^{* * *}$ & $0.7126^{* * *}$ & $0.9555^{* * *}$ \\
Debtratio & $-0.1934^{* * *}$ & $-0.1808^{* * *}$ & \\
ROA & & & $-0.2830^{* * *}$ \\
\hline
\end{tabular}




\begin{tabular}{llll}
\hline SICdum & yes & Yes & Yes \\
Adj. $R^{2}$ & 0.1917 & 0.1224 & 0.3556 \\
\hline
\end{tabular}

Panel B. Non-financial industry samples

\begin{tabular}{llll}
\hline Variable & ROE & ROA & Debtratio \\
\hline Inteceptt & $-16.3726^{* * *}$ & $-4.6080^{* * *}$ & $23.5014^{* * *}$ \\
Cash & $-0.0408^{* * *}$ & $-0.0106^{*}$ & $0.0264^{* * *}$ \\
Hucash $\times$ Cash & $0.0834^{* * *}$ & $0.0295^{* *}$ & -0.0173 \\
T $\times$ Hcash & $-4.1938^{* * *}$ & $-2.1833^{* * *}$ & 0.5988 \\
SizeD $\times$ Hcash & 0.5396 & 0.1461 & 0.0068 \\
Tenure & -0.0432 & $-0.0527^{* *}$ & $-0.0765^{* *}$ \\
Age & $0.0895^{*}$ & $0.0707^{* * *}$ & 0.0334 \\
LnTA & $3.2768^{* * *}$ & $1.5625^{* * *}$ & $2.9976^{* * *}$ \\
Mbratio & $2.1112^{* * *}$ & $0.6893^{* * *}$ & $0.9425^{* * *}$ \\
Debtratio & $-0.1915^{* * *}$ & $-0.1792^{* * *}$ & \\
ROA & & & $-0.2713^{* * *}$ \\
SICdum & Yes & Yes & Yes \\
Adj. $\mathrm{R}^{2}$ & 0.1734 & 0.1135 & 0.2540 \\
\hline
\end{tabular}

Panel C. Financial industry samples

\begin{tabular}{llll}
\hline Variable & ROE & ROA & Debtratio \\
\hline Intercept & 7.5230 & $12.0341^{* * *}$ & $34.2086^{* * *}$ \\
Cash & $-0.0769^{* * *}$ & $-0.226^{* *}$ & 0.01025 \\
Hucash $\times$ Cash & -0.0146 & 0.0086 & -0.0192 \\
T×Hcash & $-11.3012^{* * *}$ & $-2.7281^{* * *}$ & -0.3740 \\
SizeD $\times$ Hcash & $6.5912^{* * *}$ & $1.4992^{* *}$ & $1.6190^{* *}$ \\
Tenure & $0.2604^{* *}$ & 0.0511 & 0.0132 \\
Age & -0.0547 & $-0.0867^{* *}$ & 0.0404 \\
LnTA & $1.1825^{* *}$ & $0.9185^{* * *}$ & $4.0002^{* * *}$ \\
Mbratio & $4.4918^{* * *}$ & $0.8184^{* * *}$ & $1.0581^{* * *}$ \\
Debtratio & $-0.1896^{* * *}$ & $-0.1949^{* * *}$ & \\
ROA & & & $-0.4370^{* * *}$ \\
Adj. $\mathrm{R}^{2}$ & 0.4596 & 0.2380 & 0.4094 \\
\hline
\end{tabular}

Note. $\mathrm{ROE}=($ net income after tax $\div$ average shareholder equity book value $) \times 100 \%$. ROA $=($ net income after tax $\div$ average total assets $) \times 100 \%$. Debtratio $=($ total debt $\div$ total assets $) \times 100 \%$. Cash is cash compensation ratio $=[($ salary+bonus $) \div$ total compensation $] \times 100 \%$. Hucash $=1$ if the equity-based compensation ratio of the firm is higher than the median of equity-based compensation ratio of all variables; otherwise, Hucash $=0 . T$ is the dummy variable of financial crisis, before $2007, T=0$; otherwise, $T=1$.Size $D=1$, if the firm's total assets is larger than the median of the total assets for all sample firms; otherwise, SizeD $=0$. Tenure is the years the CEO has been the CEO. Age is the age of the CEO in years. TA is the total assets the firm has at the end of the year. MBratio is market value of the shareholders' equity at the end of the year : book value of the shareholder's equity at the end of the year. SICdum is measured by 7 industry dummy variables. Statistical significance is denoted by $* * *$ and $* *$ for $1 \%$ and $5 \%$ levels, respectively.

The result for the interaction between cash compensation and equity-based compensation shows that the coefficient of Hucash $\times$ Cash is significantly positive, which indicates that a higher ratio of equity-based compensation can decrease the negative effect of cash compensation on performance. However, this phenomenon is not significant in the financial industry. Secondly, the coefficient of $\mathrm{T} \times \mathrm{HCash}$ is significantly negative, which indicates that after the financial crisis, firms that pay a higher ratio of cash compensation have a poorer ROE or ROA. Finally, the coefficient of SizeD $\times$ Hcash for the financial industry is significantly positive, which indicates that while a large size and high cash payments in financial firms are beneficial to the ROE and ROA, there is also an effect on the firms' debt.

In terms of the influences of CEO traits, the ROE, the ROA, and CEO age in non-financial firms are significantly positively correlated. CEO tenure is negatively correlated with the ROA and the debt ratio. CEO age and ROA are negatively correlated in financial firms, but CEO tenure and ROE are positively correlated. This result indicates that CEOs with longer tenure in non-financial firms are inclined to be conservative, to favor 
the status quo, to follow rules and to avert risk, so there is less incentive to be enterprising (Hambrick \& Fukutomi, 1991; Hambrick, Geletkanycz, \& Fredrickson, 1993), while this may not increase earnings performance, it can inhibit risk-taking behavior in CEOs who use financial leverage. However, because they have more managerial experience and have accumulated more social and human networking resources, older non-financial firm CEOs tend to increase the debt financing capacity of the firm. This corresponds with the findings of Wiseman and Gomez-Mejia (1998) and Sitkin and Pablo (1992).

The samples are further divided into high/low performance and high/low pay groups, based on the median of the earnings performance (ROE and ROA) and the total compensation for the CEO for all of the sample firms. The distribution of industries is presented in Table 7. The result indicates that low-pay-high-performance occurs in wholesale, the retail trade and service industries, while high-pay-low-performance occurs in transportation, communication, utility, sanitary service firms and the financial, insurance and real-estate industries.

Table 7. The distribution of industries

\begin{tabular}{lllll}
\hline Industry & $\begin{array}{l}\text { High pay- } \\
\text { Low ROE }\end{array}$ & $\begin{array}{l}\text { Low pay- } \\
\text { High ROE }\end{array}$ & $\begin{array}{l}\text { High pay- } \\
\text { Low ROA }\end{array}$ & $\begin{array}{l}\text { Low pay- } \\
\text { High ROA }\end{array}$ \\
\hline Mining & $20.29^{*}$ & 20.88 & 17.06 & 25.29 \\
Construction & 12.73 & 15.45 & 12.73 & 20.91 \\
Manufacturing & 17.32 & 15.54 & 14.82 & 22.65 \\
Transportation, Communication, Utility, Sanitary Service & 26.86 & 18.92 & 37.06 & 13.92 \\
Wholesale & 24.55 & 27.73 & 25.45 & 30.00 \\
Retail Trade & 16.95 & 26.78 & 12.20 & 34.07 \\
Finance, Insurance, and Real-estate & 20.75 & 21.40 & 44.62 & 7.53 \\
Services & 10.83 & 24.72 & 11.11 & 30.97 \\
\hline
\end{tabular}

Note. The samples are divided into high and low groups based on the medians for ROE, ROA, and CEO compensation for whole samples. \# indicate the percentage of the group's observation to the total observation of the industry.

Table 8. Difference tests for high-pay-low-performance and low-pay-high-performance

\begin{tabular}{|c|c|c|c|c|c|c|}
\hline \multirow[b]{2}{*}{ Variable } & \multicolumn{3}{|c|}{ ROE } & \multicolumn{3}{|c|}{ ROA } \\
\hline & $\begin{array}{l}\text { High-pay } \\
\text { Low-ROE }\end{array}$ & $\begin{array}{l}\text { High-pay } \\
\text { Low-ROE }\end{array}$ & t-test & $\begin{array}{l}\text { High-pay } \\
\text { Low-ROA }\end{array}$ & $\begin{array}{l}\text { High-pay } \\
\text { Low-ROA }\end{array}$ & t-test \\
\hline \multicolumn{7}{|c|}{ Performance and leverage } \\
\hline ROE & $1.18^{\S}$ & 20.47 & $-32.383 * * *$ & 4.40 & 18.28 & $-23.587 * * *$ \\
\hline ROA & 0.40 & 8.91 & $-32.820 * * *$ & 0.09 & 9.17 & $-41.405^{* * *}$ \\
\hline Debtratio & 58.55 & 51.82 & $8.508 * * *$ & 68.84 & 41.74 & $42.157^{* * *}$ \\
\hline \multicolumn{7}{|l|}{ CEO pay } \\
\hline Cash & 22.67 & 54.75 & $-39.327 * * *$ & 23.99 & 53.92 & $-38.017 * * *$ \\
\hline Ucash & 77.32 & 45.24 & $39.327 * * *$ & 76.005 & 46.07 & $38.017^{* * *}$ \\
\hline \multicolumn{7}{|l|}{ CEO traits } \\
\hline Tenure & 7.08 & 8.79 & $-6.261 * * *$ & 6.99 & 9.07 & $-7.885^{* * *}$ \\
\hline Age & 56.11 & 56.07 & 0.122 & 56.60 & 56.16 & 1.445 \\
\hline \multicolumn{7}{|c|}{ Firm characteristics } \\
\hline $\mathrm{TA}$ & 34954 & 5054 & $8.299 * * *$ & 51572 & 2317 & $12.727 * * *$ \\
\hline MBratio & 1.99 & 3.33 & $-16.285^{* * *}$ & 2.13 & 3.17 & $-12.129 * * *$ \\
\hline Observations & $\begin{array}{c}1402 \\
(1948 \%\end{array}$ & $\begin{array}{c}1399 \\
(1919 \%)\end{array}$ & & 1576 & $\begin{array}{c}1572 \\
(2156 \%)\end{array}$ & \\
\hline
\end{tabular}

Note. $\mathrm{ROE}=($ net income after tax $\div$ average shareholder equity book value $) \times 100 \%$. $\mathrm{ROA}=($ net income after tax $\div$ average total assets $) \times 100 \%$. Debtratio $=$ (total debt $\div$ total assets) $\times 100 \%$. Cash is cash compensation ratio $=[($ salary+bonus $) \div$ total compensation $] \times 100 \%$. Ucash is equity-based compensation ratio=[(total compensation-cash compensation) $\div$ total compensation] $\times 100 \%$. Tenure is the years the CEO has been the CEO. Age is the age of the CEO in years. TA is the total assets the firm has at the end of the year. MBratio is market value of the shareholders' equity at the end of the year:book value of the shareholder's equity at the end of the year. $\S$ indicates the mean. Statistical significance is denoted by ${ }^{* * *}$ for $1 \%$ levels. The note of "a" represents the average of the group. \# indicates the percentage in 7290 observations. 
A two sample t-test is used to determine the difference between high-pay-low-performance firms and low-pay-high-performance firms. The results are presented in Table 8 . The result shows that high-pay-low-performance firms are mostly large, with high debt and their CEO compensation structures are mainly incentive payments (with an average equity-based compensation ratio of $77.32 \%$ ). However, incentive compensation does not significantly increase the ROE or the ROA. Low-pay-high-performance firms tend to be small. Their CEO compensation tends to have a balanced compensation structure (the average cash compensation ratio and equity-based compensation ratio are $54.75 \%$ and $45.24 \%$, respectively) and firm performance is significantly higher than that for high-pay-low-performance firms.

Non-financial firms with low-pay-high-performance and with high-pay-low-performance are also analyzed and the results are presented in Table 9. Panel A of Table 9 shows that for low-pay-high-performance firms, high equity-based compensation decreases the negative effect of cash compensation on the ROE and the ROA. After the financial crisis, cash compensation is significantly positively correlated with ROE and ROA. CEO tenure and debt are significantly negatively correlated. Panel B of Table 9 shows that for high-pay-low-performance firms, the cash compensation ratio is significantly positively correlated with the ROE, the ROA and the debt ratio. After the financial crisis, high cash compensation is significantly negatively correlated with ROE and ROA. In addition, CEO tenure and ROA are significantly negatively correlated, but CEO age is significantly positively correlated with ROE and ROA. Neither CEO traits, nor the debt ratio have any significant correlation.

These results show that, for low-pay-high-performance firms, the firm's financial performance is mainly influenced by the firm's size, growth opportunity and financial leverage. CEO compensation and traits do not have a significant influence. However, for high-pay-low-performance firms, because the compensation structures for high-pay firms are primarily based on equity-based compensation, when the firm is underperforming, cash compensation is a greater incentive for increasing earnings performance. A greater CEO age also has a positive effect on the firm's earnings performance.

\subsection{Sensitivity Analysis}

Leone et al. (2006) found that an ex post adjustment for CEO cash compensation has a higher sensitivity to low earnings performance than to high earnings performance. Shaw and Zhang (2010) found that CEO compensation has a lower sensitivity to low earnings performance than to high earnings performance; i.e., there is an asymmetric relationship between the sensitivity of CEO compensation and high/low performance. Dechow (2006), Holthausen, Larcher, and Sloan (1995) and Shaw and Zhang (2010) also showed that for low or high performance, CEO compensation has a low sensitivity to earnings performance. Hallock et al. (2010) used a quantile regression model for the analysis of pay-for-performance and found that the relationship between the two is affected by the level of CEO compensation and the current degree of heterogeneity.

Table 9. Estimates both low-pay-high-performance and high-pay-low-performance regression for non-financial firms

Panel A. Low-pay-high-performance

\begin{tabular}{llll}
\hline Variable & ROE & ROA & Debtratio \\
\hline Intercept & $13.0143^{* * *}$ & $15.3976^{* * *}$ & $9.2758^{* *}$ \\
& $(4.8293)^{\S}$ & $\left(9.6897^{* * *}\right)$ & $\left(9.2120^{*}\right)$ \\
Cash & -0.0117 & -0.0012 & -0.0152 \\
& $(-0.0067)$ & $(0.0058)$ & $(-0.0022)$ \\
Hucash $\times$ Cash & $-0.090^{* * *}$ & $-0.0233^{* *}$ & 0.0109 \\
& $\left(-0.0697^{* *}\right)$ & $\left(-0.0224^{* *}\right)$ & $(0.0162)$ \\
T×Hcash & $2.3651^{* * *}$ & $1.0180^{* * *}$ & -0.0283 \\
& $\left(1.7732^{* * *}\right)$ & $\left(0.7634^{* * *}\right)$ & $(0.6615)$ \\
SizeD $\times$ Hcash & $2.6592^{* * *}$ & $0.5593^{*}$ & 0.9506 \\
& $\left(3.2935^{* * *}\right)$ & $(0.5543)$ & $(-0.1717)$ \\
Tenure & -0.0249 & -0.0128 & $-0.1038^{*}$ \\
& $(0.0064)$ & $(0.0002)$ & $\left(-0.0926^{*}\right)$ \\
Age & 0.0697 & 0.0070 & 0.0838 \\
& $(0.0405)$ & $(-0.0023)$ & $(0.0686)$ \\
LnTA & $-1.4917^{* * *}$ & $-0.3186^{* * *}$ & $5.9508^{* * *}$ \\
& $\left(-1.0224^{* * *}\right)$ & $(-0.1350)$ & $\left(4.7853^{* * *}\right)$ \\
\hline
\end{tabular}




\begin{tabular}{llll}
\hline MBratio & $2.7181^{* * *}$ & $0.7768^{* * *}$ & $1.5506^{* * *}$ \\
& $\left(2.7396^{* * *}\right)$ & $\left(0.9203^{* * *}\right)$ & $\left(1.4833^{* * *}\right)$ \\
Debtratio & $0.1186^{* * *}$ & $-0.1438^{* * *}$ & \\
& $\left(0.2032^{* * *}\right)$ & $\left(-0.0840^{* * *}\right)$ & $-1.5004^{* * *}$ \\
ROA & & & $\left(-0.7967^{* * *}\right)$ \\
& & & Yes \\
SICdum & Yes & Yes & 0.5621 \\
Adj. $\mathrm{R}^{2}$ & 0.4833 & 0.6381 & $(0.2849)$ \\
& $(0.5253)$ & $(0.4397)$ & \\
\hline
\end{tabular}

Panel B. High-pay-low-performance

\begin{tabular}{|c|c|c|c|}
\hline Variable & ROE & ROA & Debtratio \\
\hline Intercept & $\begin{array}{l}-16.9839 * * * \\
(-28.4605)^{\S}\end{array}$ & $\begin{array}{l}-8.3898 * * * \\
(-13.8794 * * *)\end{array}$ & $\begin{array}{l}-2.4648 \\
\left(15.1849^{* * *}\right)\end{array}$ \\
\hline Cash & $\begin{array}{l}0.0816^{* *} \\
\left(0.0746^{*}\right)\end{array}$ & $\begin{array}{l}0.0581 * * * \\
(0.0362)\end{array}$ & $\begin{array}{l}0.0745^{* * *} \\
\left(0.0533^{* * *}\right)\end{array}$ \\
\hline Hucash $\times$ Cash & $\begin{array}{l}-0.0954 \\
(0.0008)\end{array}$ & $\begin{array}{l}-0.0686^{* *} \\
(-0.0363)\end{array}$ & $\begin{array}{l}-0.0709^{*} \\
(-0.0464)\end{array}$ \\
\hline $\mathrm{T} \times$ Hcash & $\begin{array}{l}-4.3090^{*} \\
(-7.5292 * * *)\end{array}$ & $\begin{array}{l}-1.8047 \\
(-1.4417)\end{array}$ & $\begin{array}{l}1.3450 \\
(0.2940)\end{array}$ \\
\hline SizeD $\times$ Hcash & $\begin{array}{l}3.6505^{*} \\
(2.3630)\end{array}$ & $\begin{array}{l}0.5001 \\
(0.5493)\end{array}$ & $\begin{array}{l}-0.3137 \\
(0.4819)\end{array}$ \\
\hline Tenure & $\begin{array}{l}-0.0769 \\
(0.0114)\end{array}$ & $\begin{array}{l}-0.0699^{*} \\
\left(-0.0721^{*}\right)\end{array}$ & $\begin{array}{l}-0.0893 \\
(0.0452)\end{array}$ \\
\hline Age & $\begin{array}{l}0.1464 * \\
(0.0783)\end{array}$ & $\begin{array}{l}0.0795^{* *} \\
\left(0.0935^{* *}\right)\end{array}$ & $\begin{array}{l}-0.0278 \\
(-0.0819)\end{array}$ \\
\hline LnTA & $\begin{array}{l}2.6430 * * * \\
(2.3931 * * *)\end{array}$ & $\begin{array}{l}0.7987^{* * *} \\
(0.8394 * * *)\end{array}$ & $\begin{array}{l}5.3744 * * * \\
(3.7918 * * *)\end{array}$ \\
\hline MBratio & $\begin{array}{l}-0.7959 * * * \\
(-0.0811)\end{array}$ & $\begin{array}{l}-0.1940^{*} \\
(0.0028)\end{array}$ & $\begin{array}{l}0.8794 * * * \\
(0.6317 * * *)\end{array}$ \\
\hline Debtratio & $\begin{array}{l}-0.3139 * * * \\
(-0.0168)\end{array}$ & $\begin{array}{l}-0.1064 * * * \\
(-0.0205)\end{array}$ & \\
\hline ROA & & & $\begin{array}{l}-0.2885 * * * \\
(-0.1553 * * *)\end{array}$ \\
\hline SICdum & Yes & Yes & Yes \\
\hline Adj. $R^{2}$ & $\begin{array}{l}0.0887 \\
(0.0868)\end{array}$ & $\begin{array}{l}0.0617 \\
(0.0489)\end{array}$ & $\begin{array}{l}0.4030 \\
(0.4273)\end{array}$ \\
\hline
\end{tabular}

Note. $\S$ indicates the earning performance is measured by ROA. ROE $=($ net income after tax $\div$ average shareholder equity book value $) \times 100 \%$. $\mathrm{ROA}=$ (net income after tax $\div$ average total assets) $\times 100 \%$. Debtratio $=($ total debt $\div$ total assets) $\times 100 \%$. Cash is cash compensation ratio $=[$ (salary+bonus) $\div$ total compensation $] \times 100 \%$. Hucash $=1$ if the equity-based compensation ratio of the firm is higher than the median of equity-based compensation ratio of all variables; otherwise, Hucash $=0 . T$ is the dummy variable of financial crisis, before $2007, T=0$; otherwise, $\mathrm{T}=1 . \mathrm{SizeD}=1$, if the firm's total assets is larger than the median of the total assets for all sample firms; otherwise, Size $\mathrm{D}=0$. Tenure is the years the CEO has been the CEO. Age is the age of the CEO in years. TA is the total assets the firm has at the end of the year. MBratio is market value of the shareholders'equity at the end of the year $\div$ book value of the shareholder's equity at the end of the year. SICdum is measured by 7 industry dummy variables. Statistical significance is denoted by $* * *, * *$ and $*$ for $1 \%, 5 \%$ and $10 \%$ levels, respectively.

Since conditional quantile regression can be used to determine the heterogeneity of dependent variables and independent variables for different quantile levels, it can avoid the flaws of traditional regression models in assuming that the population distribution is normal and base its analysis on the mean. Therefore, the quantile regression model proposed by Koenker and Bassetst (1978) is used to analyze the earnings performance and financial leverage at the $0.1,0.5$ and 0.9 quantiles, to determine whether there is asymmetry in the relationships between CEO compensation and traits and the ROE, the ROA and the debt ratio. The results are presented in Table 10. 
Table 10. Results of sensitivity analysis

Panel A. ROE

\begin{tabular}{|c|c|c|c|c|c|c|}
\hline Variable & 0.1 Quantile & & 0.5 Quantile & & 0.9 Quantile & \\
\hline Cash & $-0.059 * * *$ & & $-0.018^{* *}$ & & $-0.024 * *$ & \\
\hline Ucash & & $-0.020 *$ & & 0.006 & & 0.014 \\
\hline Tenure & $-0.123 * * *$ & $-0.113 * *$ & -0.005 & -0.005 & 0.029 & 0.028 \\
\hline Age & $-0.323 * * *$ & $-0.392 * * *$ & -0.036 & $-0.054 * *$ & 0.012 & -0.017 \\
\hline LnTA & $3.135 * * *$ & $3.445 * * *$ & $0.554 * * *$ & $0.575 * * *$ & $0.385^{* *}$ & $0.381^{*}$ \\
\hline MBratio & $1.996 * * *$ & $2.222 * * *$ & $3.888 * * *$ & $3.879 * * *$ & $6.235^{* * *}$ & $6.242 * * *$ \\
\hline Debtratio & $-0.173 * * *$ & $-0.182 * * *$ & $0.035 * * *$ & $0.033^{* *}$ & $0.055 * * *$ & $0.053 * * *$ \\
\hline
\end{tabular}

Panel B. ROA

\begin{tabular}{|c|c|c|c|c|c|c|}
\hline Variable & 0.1 Quantile & & 0.5 Quantile & & 0.9 Quantile & \\
\hline Cash & $-0.019 * * *$ & & 0.003 & & 0.005 & \\
\hline Ucash & & -0.004 & & 0.003 & & 0.008 \\
\hline Age & $-0.122 * * *$ & $-0.142 * * *$ & $0.071 * * *$ & $0.074 * * *$ & $0.136 * * *$ & $0.138 * * *$ \\
\hline LnTA & 1.188 & $1.303 * * *$ & $0.486 * * *$ & $0.442 * * *$ & $0.534 * * *$ & $0.443 * * *$ \\
\hline Debtratio & $-0.067 * * *$ & $-0.073 * * *$ & $-0.111 * * *$ & $-0.110 * * *$ & $-0.153 * * *$ & $-0.147 * * *$ \\
\hline
\end{tabular}

Panel C. Debtratio

\begin{tabular}{|c|c|c|c|c|c|c|}
\hline Variable & 0.1 Quantile & & 0.5 Quantile & & 0.9 Quantile & \\
\hline Cash & -0.0017 & & $0.037 * * *$ & & $0.096 * * *$ & \\
\hline Ucash & & $-0.044 * * *$ & & $-0.048 * * *$ & & -0.011 \\
\hline Tenure & $-0.1757 * * *$ & $-0.229 * * *$ & $-0.338 * * *$ & $-0.363 * * *$ & $-0.114^{*}$ & $0.164 * *$ \\
\hline Age & $-0.1960 * * *$ & $-0.167 * * *$ & $0.189 * * *$ & $0.246^{* * *}$ & $0.710 * * *$ & $0.875 * * *$ \\
\hline ROA & $-0.2661 * * *$ & $-0.275^{* * *}$ & $-0.969 * * *$ & $-0.966 * * *$ & $-1.973^{* * *}$ & $-1.973 * * *$ \\
\hline LnTA & $6.2539 * * *$ & $6.454 * * *$ & $6.470 * * *$ & $6.644 * * *$ & $4.759 * * *$ & $4.243 * * *$ \\
\hline MBratio & $-0.6405 * * *$ & $-0.631 * * *$ & $0.772 * * *$ & $0.781 * * *$ & $2.356 * * *$ & $2.337 * * *$ \\
\hline
\end{tabular}

Note. $\mathrm{ROE}=($ net income after tax $\div$ average shareholder equity book value $) \times 100 \% . \mathrm{ROA}=($ net income after tax $\div$ average total assets $) \times 100 \%$. Debtratio $=($ total debt $\div$ total assets $) \times 100 \%$. Cash is cash compensation ratio $=[($ salary+bonus $) \div$ total compensation $] \times 100 \%$. Ucash is equity-based compensation ratio $=[$ (total compensation-cash compensation $) \div$ total compensation $] \times 100 \%$. Tenure is the years the CEO has been the CEO. Age is the age of the CEO in years. LnTA is the natural logarithm of total assets the firm has at the end of the year. MBratio is market value of the shareholders' equity at the end of the year-book value of the shareholder's equity at the end of the year. Statistical significance is denoted by $* * * * *$ and $*$ for $1 \%, 5 \%$ and $10 \%$ levels, respectively.

Panel A of Table 10 shows that, overall, cash compensation and the ROE are significantly negatively correlated. The effect is greater for the 0.1 and 0.9 quantiles than for the 0.5 quantile. In addition, for a low ROE $(0.1$ quantile), equity-based compensation has a significant negative correlation, but when the ROE is increased $(0.5$ and 0.9 quantiles) a positive but insignificant correlation begins to appear. This result shows that cash compensation does not increase the ROE and equity-based compensation reduces the ROE for low levels of ROE. In addition, for low levels of ROE (0.1 quantile), CEO tenure and age are significantly negatively correlated with ROE, but the degree of negative correlation decreases as the ROE increases, which indicates that, for a low ROE, longer CEO tenure and higher CEO age are detrimental to increasing the ROE.

Panel B of Table 10 shows that cash compensation only has a significant negative correlation for a low ROA $(0.1$ quantile), which indicates that cash compensation does not increase a low ROA. In addition, for a low ROA (0.1 quantile), CEO tenure and age are significantly negatively correlated with the ROA, but the negative correlation decreases as the ROA increases, especially for a medium or high ROA. CEO age has a significant positive correlation, which shows that older CEOs are more experienced and can help to increase the ROA. However, for a low ROA, longer tenure and older age can be detrimental to the creation of innovative new strategies, because of rigidity and conservative tendencies in managerial thinking. 
Panel $\mathrm{C}$ of Table 10 shows that, for medium and high debt ( 0.5 and 0.9 quantiles), cash compensation has a significant positive correlation, but equity-based compensation has a significant negative correlation for medium and low debt ( 0.1 and 0.5 quantiles). This result shows that, because cash compensation is a guaranteed compensation, it can lead to an increase in the moral risk of CEOs using financial leverage to take risks. However, because higher debt means a greater bankruptcy risk for the firm, this is not beneficial to the future value of the CEO's equity-based compensation, so CEO's are deterred from using financial leverage to take risks out of self-interest. In addition, for low and medium debt (0.1 and 0.5 quantiles), CEO tenure has a significant negative correlation, which indicates that CEOs with longer tenure have a more conservative attitude to debt financing. However, CEO age has a significant negative correlation for low debt (0.1 quantile), but a significant positive correlation for medium and high debt ( 0.5 and 0.9 quantiles), which indicates that older CEOs can increase the firm's debt leverage capacity because they have more managerial experience, better risk management capabilities and better people skills.

In summary, for low earnings performance, cash compensation and equity-based compensation do not have a positive effect. However, for medium or high debt, cash compensation has a positive effect on debt financing, but for medium or low debt, equity-based compensation can inhibit the CEO from using financial leverage to take risks. In addition, for low earnings performance and low debt, while longer tenure and a greater age are not beneficial to generating earnings, they can decrease the risks taken in debt financing. For medium or high earnings performance and high debt, an older CEO can help to increase the firm's ROA and debt capacity, because there is more managerial experience, greater risk management capability and better people skills.

\section{Conclusion}

In an agency relationship, CEO traits and compensation systems are important internal corporate governance variables that coordinate the conflicts of interests between the management and shareholders. Therefore, a random effect panel model is used to determine the impact of CEO traits and compensation on earnings performance and financial leverage, using the panel data for 729 US firms from ExecuComp, over the period, 2001-2010.

The empirical results show that because of its fixed or guaranteed nature, cash compensation has a lower correlation with a firm's earnings performance. Therefore, a higher ratio of cash compensation can have a negative impact on a firm's earnings performance. It can also decrease the sensitivity of the CEO to the financial risk generated by debt financing and can have a positive impact on debt financing. In contrast, because equity-based compensation is variable in nature, it has a direct relationship with performance. Therefore, a higher ratio of equity-based compensation can increase the return on shareholder's equity. Because debt financing can increase the firm's bankruptcy risk and result in a decrease in the future value of any equity-based compensation, it can inhibit risk-taking using the firm's debt financing. A higher ratio of equity-based compensation can also decrease the negative effect of cash compensation on performance. This study also finds that, while it may not lead to an increase in earnings, longer CEO tenure can inhibit risky debt financing. In contrast, an older CEO can increase the firm's earnings performance and the firm's debt financing capacity. Finally, the sensitivity analysis results show that, for low earnings performance, cash compensation and equity-based compensation do not have a positive effect. However, for medium or high debt, cash compensation has a positive effect on debt financing. For medium or low debt, equity-based compensation can inhibit a CEO from taking risks by using financial leverage. In addition, for low earnings performance and low debt, while longer tenure and older age are not beneficial to earnings performance, they can decrease the risks taken in debt financing. For medium and high earnings performance and debt, an older CEO can increase the firm's ROA and increase its debt financing capacity.

Since this study views CEO traits and compensation as mutually independent factors, future research might determine whether there is an interaction between traits and compensation. In addition, some studies found that CEO compensation and performance are highly endogenous, as a future research, we seek to extend the study to discuss the reversal causality concern.

\section{Acknowledgments}

This study is fully financial supported by National Science Council in Taiwan, NSC contract No. NSC 100-2410-H-147-007.

\section{References}

Abowd, J. (1990). Does performance-based managerial compensation affect corporate performance? Industrial and Labor Relations Review, 43(3), 52-73. http://dx.doi.org/10.2307/2523571 
Alderfer, C. P. (1986). The invisible director on corporate boards. Harvard Business Review, 64(6), 38-52.

Antia, M., Pantzalis, C., \& Park, J. C. (2010). CEO Decision horizon and firm performance: An empirical investigation. Journal of Corporate $288-301$. http://dx.doi.org/10.1016/j.jcorpfin.2010.01.005

Balachandran, S., \& Mohanram, P. (2010). Are CEOs Compensated for Value Destroying Growth in Earnings? Review of Accounting Studies, 15(3), 545-577. http://dx.doi.org/10.1007/s11142-010-9136-1

Bantel, K. A. (1994). Strategic planning openness: The role of top team demography. Group and Organization Management, 19(4), 406-424. http://dx.doi.org/10.1177/1059601194194002

Berger, P. G., Ofek, E., \& Yermack, D. L. (1997). Managerial entrenchment and capital structure. Journal of Finance, 52(4), 1411-1438. http://dx.doi.org/10.1111/j.1540-6261.1997.tb01115.x

Bergmann, J. J., \& Scarpello, V. G. (2002). Compensation decision making. South Western, Australia.

Bertrand, M., \& Schoar, A. (2003). Managing with style: The effect of managers on firm policies. Quarterly Journal of Economics, 118(4), 1169-1208. http://dx.doi.org/10.1162/003355303322552775

Bloodgood, J. M., Sapienza, H. J., \& Almeida, J. G. (1996). The Internationalization of new high-potential U.S. ventures: Antecedents and outcomes. Entrepreneurship Theory and Practice, 20(4), 61-75.

Brick, I., Palmon, O., \& Wald, I. (2006). CEO compensation, director compensation, and firm performance: Evidence of cronyism? Journal of Corporate Finance, 12(3), 403-423. http://dx.doi.org/10.1016/j.jcorpfin.2005.08.005

Brockman, P., Martin, X., \& Unlu, E. (2010). Executive compensation and the maturity structure of corporate debt. Journal of Finance, 65(3), 1123-1162. http://dx.doi.org/10.1111/j.1540-6261.2010.01563.x

Buck, T., Bruce, A., Main, B., \& Udueni, H. (2003). Long term incentive plans, executive pay and UK company performance. Journal of Management Studies, $40(7), \quad 1709-1721$. http://dx.doi.org/10.1111/1467-6486.00397

Bulan, L., Sanyal, P., \& Yan, Z. (2010). A few bad apples: An analysis of CEO performance pay and firm productivity. Journal of Economics and Business, 62(4), 273-306. http://dx.doi.org/10.1016/j.jeconbus.2010.02.001

Burgelman, R. (1991). Intraorganizational ecology of strategy making and organizational adaptation: Theory and field research. Organization Science, 2(2), 239-262. http://dx.doi.org/10.1287/orsc.2.3.239

Carpenter, J. N. (2000). Does option compensation increase managerial risk appetite? Journal of Finance, 55(5), 2311-2331. http://dx.doi.org/10.1111/0022-1082.00288

Carpenter, M. A., Pollock, T. G., \& Leary, M. M. (2003). Testing a model of reasoned risk-taking: Governance, the experience of principals and agents, and global strategy in high-technology IPO firms. Strategic Management Journal, 24(9), 803-820. http://dx.doi.org/10.1002/smj.338

Carpenter, M. A., Sanders, W. G., \& Gregersen, H. B. (2001). Bundling human capital with organizational context: The impact of international assignment experience on multinational firm performance and CEO pay. Academy of Management Journal, 44(3), 493-511. http://dx.doi.org/10.2307/3069366

Carter, M. E., Lynch, L., \& Tuna, I. (2007). The role of accounting in the design of CEO equity compensation. The Accounting Review, 82(2), 327-357. http://dx.doi.org/10.2308/accr.2007.82.2.327

Chang, Y. Y., Dasgupta, S., \& Hilary, G. (2010). CEO ability, pay, and firm performance. Management Science, 56(10), 1633-1652. http://dx.doi.org/10.1287/mnsc.1100.1205

Chava, S., \& Purnanandam, A. (2010). CEOs versus CFOs: Incentive and corporate polices. Journal of Financial Economics, 97(2), 263-278. http://dx.doi.org/10.1016/j.jfineco.2010.03.018

Chen, C., Steiner, T., \& Whyte, A. (2006). Does stock option-based executive compensation induce risk-taking? An analysis of the banking industry. Journal of Banking and Finance, 30(3), 915-945. http://dx.doi.org/10.1016/j.jbankfin.2005.06.004

Coles, J. L., Daniel, N. D., \& Naveen, L. (2006). Managerial incentives and risk-taking. Journal of Financial Economics, 79(2), 431-468. http://dx.doi.org/10.1016/j.jfineco.2004.09.004

Core, I., Holthausen, R., \& Larcker, D. (1999). Corporate governance, chief executive officer, and firm performance. Journal of Financial Economics, 51(3), 371-406. 
http://dx.doi.org/10.1016/S0304-405X(98)00058-0

Core, J., \& Guay, W. (1999). The use of equity grants to manage optimal equity incentive levels. Journal of Accounting and Economics, 28(2), 151-184. http://dx.doi.org/10.1016/S0165-4101(99)00019-1

Coughlan, A. T., \& Schmidt, R. M. (1985). Executive compensation, management turnover, and firm performance: An empirical investigation. Journal of Accounting and Economics, 7(1), 43-66. http://dx.doi.org/10.1016/0165-4101(85)90027-8

Dalton, D. R., Daily, C. M., Certo, S. T., \& Roengpitya, R. (2003). Meta-analyses of financial performance and equity: Fusion or confusion? Academy of Management Journal, 46(1), 13-26. http://dx.doi.org/10.2307/30040673

Datta, S., Iskandar-Datta, M., \& Raman, K. (2001). Executive compensation and corporate acquisition decisions. Journal of Finance, 56(6), 2299-2336. http://dx.doi.org/10.1111/0022-1082.00406

Dechow, P. M., \& Sloan, R. G. (1991). Executive incentives and horizon problem. Journal of Accounting and Economics, 14(1), 51-89. http://dx.doi.org/10.1016/0167-7187(91)90058-S

Dechow, P. M. (2006). Asymmetric sensitivity of CEO cash compensation to stock returns: A discussion. Journal of Accounting and Economics, 42(1), 193-202. http://dx.doi.org/10.1016/j.jacceco.2005.11.001

Dong, Z., Wang, C., \& Xie, F. (2010). Do executive stock options induce excessive risk taking? Journal of Banking and Finance, 34(10), 2518-2529. http://dx.doi.org/10.1016/j.jbankfin.2010.04.010

Duffhues, P. J. W., \& Kabir, M. R. (2008). Is the pay-performance relationship always positive? Evidence from the Netherlands. Journal of Multinational Financial Management, 18(1), 45-60. http://dx.doi.org/10.1016/j.mulfin.2007.02.004

Eisenhardt, K. M., \& Schoonhoven, C. B. (1990). Organizational growth: Linking founding team, strategy, environment, and growth among U.S. semiconductor ventures. Administrative Science Quarterly, 35(3), 504-529. http://dx.doi.org/10.2307/2393315

Fahlenbrach, R. (2009). Shareholder rights, boards and ceo compensation. Review of Finance, 13(1), 81-113. http://dx.doi.org/10.1093/rof/rfn011

Fama, E. F., \& Jensen, M. C. (1983). Separation of ownership and control. Journal of Law and Economics, 26(2), 301-325. http://dx.doi.org/10.1086/467037

Fernandes, N. (2008). Board compensation and firm performance: The role of "independent" board members. Journal of Multinational Financial Management, $18(1), \quad 30-44$. http://dx.doi.org/10.1016/j.mulfin.2007.02.003

Finkelstein, S., \& Hambrick, D. C. (1990). Top management team tenure and organizational outcomes: The moderating role of managerial discretion. Administrative Science Quarterly, 35(3), 484-503. http://dx.doi.org/10.2307/2393314

Golden, B., \& Zajac, E. J. (2001). When will boards influence strategy? Inclination $\times$ Power=Strategic change. Strategic Management Journal, 22(12), 1087-1111. http://dx.doi.org/10.1002/smj.202

Grimm, C. M., \& Smith, K. G. (1991). Management and organizational change: A note on the railroad industry. Strategic Management Journal, 12(7), 557-562. http://dx.doi.org/10.1002/smj.4250120708

Hall, B. J., \& Liebman, J. B. (1998). Are CEOs really paid like bureaucrats? Quarterly Journal of Economics, 113(3), 653-691. http://dx.doi.org/10.1162/003355398555702

Hallock, K. F., Madlozzo, R., \& Reck, C. G. (2010). CEO pay-for-performance heterogeneity using quantile regression. The Financial Review, 45(1), 1-19. http://dx.doi.org/10.1111/j.1540-6288.2009.00235.x

Hambrick, D. C., \& D’Aveni, R. A. (1992). Top team deterioration as part of the downward spiral of large corporate bankruptcies. Management $\quad$ Science, $\quad 38(10), \quad$ 1445-1466. http://dx.doi.org/10.1287/mnsc.38.10.1445

Hambrick, D. C., \& Fukutomi, G. D. S. (1991). The seasons of CEO's tenure. Academy of Management Review, 16(4), 719-742.

Hambrick, D. C., \& Mason, P. (1984). Upper echelons: The organization as a reflection of its top managers. Academy of Management Review, 9(2), 193-206.

Hambrick, D. C., Geletkanycz, M. A., \& Fredrickson, J. W. (1993). Top executive commitment to the status quo: 
Some tests of its determinants. Strategic Management Journal, 14(6), 401-418. http://dx.doi.org/10.1002/smj.4250140602

Hill, C. W., \& Phan, P. (1991). CEO tenure as a determinant of CEO pay. Academy of Management Journal, 34(3), 712-717. http://dx.doi.org/10.2307/256413

Hitt, M., \& Tyler, B. (1991). Strategic decision models: Integrating different perspectives. Strategic Management Journal, 12(5), 327-363. http://dx.doi.org/10.1002/smj.4250120502

Holthausen, R., Larcher, D., \& Sloan, R. (1995). Annual bonus schemes and the manipulation of earnings. Journal of Accounting and Economics, 19(1), 29-74. http://dx.doi.org/10.1016/0165-4101(94)00376-G

Jensen, M. C., \& Meckling, W. H. (1976). Theory of the firm: Managerial behavior, agency costs and ownership $\begin{array}{lllll}\text { structure. Journal of } & \text { Financial }\end{array}$ http://dx.doi.org/10.1016/0304-405X(76)90026-X

Jensen, M. C., \& Meckling, W. H. (1979). Rights and production functions: An application to labor-managed firms and codetermination. Journal of Business, 52(4), 469-506. http://dx.doi.org/10.1086/296060

Jensen, M., \& Murphy, K. (1990). Performance pay and top management incentives. Journal of Political Economy, 98(2), 225-264. http://dx.doi.org/10.1086/261677

Kato, T., \& Kubo, K. (2006). CEO compensation and firm performance in Japan: Evidence from new panel data on individual CEO pay. Journal of Japanese and International Economies, 20(1), 1-19. http://dx.doi.org/10.1016/j.jjie.2004.05.003

Kaymak, T., \& Bektas, E. (2008). East meets west? Board characteristics in an emerging market: Evidence from Turkish banks. Corporate Governance, 16(6), 550-561. http://dx.doi.org/10.1111/j.1467-8683.2008.00713.x

Knopf, J. D., Nam, J., \& Thornton Jr., J. H. (2002). The volatility and price sensitivities of managerial stock option portfolios and corporate hedging. Journal of Finance, 57(2), 801-812. http://dx.doi.org/10.1111/1540-6261.00442

Koenker, R., \& Bassett, G. (1978). Regression quantile. Econometrica, 46(1), $33-50$. http://dx.doi.org/10.2307/1913643

Krishnan, H. A., Miller, A., \& Judge, W. Q. (1997). Diversification and top management team complementarity: Is performance improved by merging similar or dissimilar teams? Strategic Management Journal, 18(5), 361-374. http://dx.doi.org/10.1002/(SICI)1097-0266(199705)18:5<361::AID-SMJ866>3.0.CO;2-L

Kuo, H. C. (2000). An adaptive view of strategic change. International Journal of Business and Strategy, 1(2), $27-44$.

Leone, A., Wu, J., \& Zimmerman, I. (2006). Asymmetric sensitivity of CEO cash compensation to stock returns. Journal of Accounting and Economics, 42(1), 167-192. http://dx.doi.org/10.1016/j.jacceco.2006.04.001

Lewellen, K. (2006). Financing decisions when managers are risk averse. Journal of Financial Economics, 82(3), 551-589. http://dx.doi.org/10.1016/j.jfineco.2005.06.009

Lin, D., Kuo, H. C., \& Wang, L. H. (2013). Chief executive compensation: An empirical study of fat cat CEOs. International Journal of Business and Finance Research, 7(2), 27-42.

Lippert, R. L., \& Moore, W. T. (1995). Monitoring versus bonding: Shareholder rights and management compensation. Financial Management, 24(3), 54-62. http://dx.doi.org/10.2307/3665557

Mayers, D., \& Smith, C. W. (2010). Compensation and board structure: Evidence from the insurance industry. Journal of Risk and Insurance, 77(2), 297-327. http://dx.doi.org/10.1111/j.1539-6975.2010.01352.x

Mehran, H. (1992). Executive incentive plans, corporate control, and capital structure. Journal of Financial and Quantitative Analysis, 27(4), 539-560. http://dx.doi.org/10.2307/2331139

Melin, L. (1992). Internationalization as a strategy process. Strategic Management Journal, 13(special issue), 99-118. http://dx.doi.org/10.1002/smj.4250130908

Miller, D. J. (1995). CEO salary increases may be rational after all: Referents and contracts in CEO pay. Academy of Management Journal, 38(5), 1361-1385. http://dx.doi.org/10.2307/256861

Murphy, K. J. (1985). Corporate performance and managerial remuneration: An empirical analysis. Journal of Accounting and Economics, 7(1-3), 11-42. http://dx.doi.org/10.1016/0165-4101(85)90026-6

Murphy, K. J. (1999). Executive compensation. In O. Ashenfelter \& D. Card (Eds.), Handbook of labor 
economics (pp. 2485-2563). Amsterdam, North Holland: Elsevier Science.

Ozkan, N. (2011). CEO compensation and firm and firm performance: An empirical investigation of UK panel $\begin{array}{lllll}\text { data. } & \text { European } & \text { Financial } & \text { Management, } & \text { 17(2), }\end{array}$ http://dx.doi.org/10.1111/j.1468-036X.2009.00511.x

Palmon, O., Bar-Yosef, S., Chen, C., \& Venezia, I. (2008). Optimal strike prices of stock options for effort-averse executives. Journal of Banking and Finance, 32(4), $229-239$. http://dx.doi.org/10.1016/j.jbankfin.2007.03.015

Ross, S. A. (1973). The economic theory of agency: The principal's problem. American Economic Review, 63(2), 134-139.

Ross, S. A. (2004). Compensation, incentives, and the duality of risk aversion and riskiness. Journal of Finance, 59(1), 207-225. http://dx.doi.org/10.1111/j.1540-6261.2004.00631.x

Ryan, H. E., \& Wiggins, R. A. (2001). The influence of firm- and manager-specific characteristics on the structure of executive compensation. Journal of Corporate Finance, 7(2), 101-123. http://dx.doi.org/10.1016/S0929-1199(00)00021-3

Sanders, W. G., \& Carpenter, M. A. (1998). Internationalization and firm governance: The roles of CEO compensation, top team composition, and board structure. Academy of Management Journal, 41(2), 158178. http://dx.doi.org/10.2307/257100

Shaw, K. W., \& Zhang, M. H. (2010). Is CEO cash compensation punished for poor firm performance? Accounting Review, 85(3), 1065-1093. http://dx.doi.org/10.2308/accr.2010.85.3.1065

Shen, W. (2003). The dynamics of the CEO board relationship: An evolutionary perspective. Academy of Management Review, 28(3), 466-470.

Simeon, R. (2001). Top team characteristics and the business strategies of Japanese firms. Corporate Governance, 1(2), 4-12. http://dx.doi.org/10.1108/14720700110394344

Sitkin, S., \& Pablo, A. (1992). Reconceptualizing the determinants of risk behavior. Academy and Management Review, 17(1), 9-38.

Tchistyi, A., Yermack, D., \& Yun, H. (2011). Negative hedging: performance-sensitive debt and CEOs' equity incentives. Journal of Financial and Quantitative Analysis, 46(3), 657-686. http://dx.doi.org/10.1017/S0022109011000068

Titman, S., Wei, K. C., \& Xie, F. (2004). Capital investments and stock returns. Journal of Financial and Quantitative Analysis, 39(4), 677-700. http://dx.doi.org/10.1017/S0022109000003173

Tosi, H. L., Werner, S., Katz, J. P., \& Comez-Mejia, L. R. (2000). How much does performance matter? A meta-analysis of CEO pay studies. Journal of Management, 26(2), 301-339. http://dx.doi.org/10.1177/014920630002600207

Vafeas, N. (2003). Length of board tenure and outside director independence. Journal of Business Finance and Accounting, 30(7), 1043-1064. http://dx.doi.org/10.1111/1468-5957.05525

Wiersema, M. F., \& Bantel, K. A. (1992). Top Management Team Demography and Corporate Strategic Change. Academy of Management Journal, 35(1), 91-121. http://dx.doi.org/10.2307/256474

Wiseman, R., \& Gomez-Mejia, L. R. (1998). A behavioral agency model of risk taking. Academy and Management Review, 23(1), 133-153.

Zhou, X. (2000). CEO Pay, Firm Size, and Corporate Performance: Evidence from Canada. Journal of Economics, 33(1), 213-252.

\section{Copyrights}

Copyright for this article is retained by the author(s), with first publication rights granted to the journal.

This is an open-access article distributed under the terms and conditions of the Creative Commons Attribution license (http://creativecommons.org/licenses/by/3.0/). 